\title{
The Use of the Triad Approach to Ecological Assessment of the State of a Reservoir Receiving Wastewater From a Thermal Power Plant
}

\author{
Elena Mahanova' \\ 1 Department of Zoohygiene, Physiology and Biochemistry, Vyatka State Agricultural Academy, Oktyabrsky \\ Prospekt 133, Kirov, 610017, Kirov Region, Russia \\ e-mail: elena-makhanova@yandex.ru
}

\begin{abstract}
Thermal power plants (TPP) belong to the enterprises that accompany the development of any city. These industrial facilities consume and discharge large amounts of water. Therefore, thermal power plants are often located near water bodies that need to assess their ecological state and predict the consequences of the anthropogenic impact. The purpose of the work was to assess the ecological state of the floodplain Lake Ivanovskoye (Russia, Kirov region), which receives the wastewater from a thermal power plant, using a triadic approach and comparing the results of chemical analysis, bioassay and bioindication. It was shown that the main pollutant in the lake and the canal connecting Lake Ivanovskoye with the nearest river Vyatka is ammonium ion (up to $3.2 \mathrm{mg} / \mathrm{dm}^{3}$ ). In addition, the Russian standards for biological oxygen consumption are exceeded (analysis period is 20 days). The tests for the toxicity of wastewater showed inhibition of Paramecium caudatum and Escherichia coli reactions. In contrast, natural surface water from Lake Ivanovskoye stimulated the test functions of Scenedesmus quadricauda, P. caudatum, and E. coli. The death of Daphnia magna in the samples were not recorded. The totality of the facts pointed to the organic nature of pollution, leading to the anthropogenic eutrophication of the lake. The hypothesis was tested by using the bioindication method and by analyzing the totality of species of coastal aquatic plants. It was shown that the reservoir belongs to the mesotrophic type with a moderate degree of pollution, which decreases with distance from the wastewater discharge points. The increase in the trophicity of the reservoir is facilitated by thermal pollution (up to $+15^{\circ} \mathrm{C}$ ) and an alkaline $\mathrm{pH}$ of wastewater (up to 9.2). Thus, the joint analysis of the results of chemical analysis, bioassay and bioindication made it possible to carry out an objective assessment of the ecological state of the reservoir and identify the reasons for the revealed facts.
\end{abstract}

Keywords: thermal power plant, chemical analysis of water, bioassay, bioindication, pollution, trophicity

\section{INTRODUCTION}

The increasing anthropogenic load on the environment requires legislative environmental protection measures which are developed taking into account the achievements of science. The positive examples of this tendency are the Water Framework Directive (WFD) adopted in the European Union and the Water Code in the Russian Federation. The WFD and the Water Code support an integrated approach in assessing the ecological state of water bodies, since it is known that the most objective information about the environmental component is formed through a joint analysis of the hydrochemical, hydrobiological and ecotoxicological data. [Directive 2000/60/EC 2000; Water Code of the Russian Federation 2006].

This concept complies with the triadic approach proposed in 1986 by Chapman for assessing the quality and ecological state of precipitation [Chapman 1986]. Since then, scientists also have begun to apply this approach actively to assess the environmental risks of anthropogenic pollution and predict its consequences for soils and natural waters [Klimkowicz-Pawlas, Maliszewska-Kordybach and Smreczak 2019; Slimani et al. 2020; Hong et al. 2020]. The triadic approach is aimed at establishing the relationships between the amount of toxicants in the environmental component, the reactions of 
experimental laboratory animals (bioassay) and the responses of organisms in the natural ecosystem (bioindication).

The choice of organisms, bioindicators and laboratory cultures for bioassay is a scientific and methodological problem. Its solution depends on the individual characteristics of the studied reservoir: the type of pollution, the degree of pollution, the biota of the water body, and others. Scientists often choose different plant species as bioindicators, since they lead an attached lifestyle and reflect the state of a specific part of the reservoir [Stesevic et al. 2007; Alemu et al. 2018]. The «battery» of biotests traditionally includes test organisms representing different trophic groups [Pandard et al. 2006; Zovko et al. 2015].

The purpose of our work was to assess the ecological state of the floodplain oxbow lake using a triadic approach and to compare the results of chemical analysis, bioassay, and bioindication.

\section{MATERIAL AND METHODS}

The object of the study was an oxboy Lake Ivanovskoye, located in the floodplain of the Vyatka River (Russia, Kirov region). The climate is temperate, the natural zone is represented with taiga forests. The main characteristics of the reservoir are given in Table 1. The lake receives the wastewater from a thermal power plant (TPP) of the city of KirovoChepetsk, located nearby. The TPP generates heat and electricity. The thermal power of the TPP - 813 Gcal/hour; electric capacity $160 \mathrm{MW}$.

The TPP discharges wastewater into Lake Ivanovskoye through two outlets. By outlet No. 1, the following merge into the lake:

- wastewater without treatment after cooling of the station units;

- industrial stormwater from the territory of the TPP;

- wastewater after chemical treatment of makeup water.

The water consumption at the first outlet is 4220.43-10321.67 m³/hour. Heated water enters the water outlet No.1 through a channel (length $0.5 \mathrm{~km}$ ), where the water is cooled and saturated with atmospheric oxygen. Water outlet No.2 is organized for blowdown waters of the ash removal system from fuel combustion at thermal power plants. These waters enter the lake without mechanical treatment. Their entry into the reservoir is $23.52-55.11 \mathrm{~m}^{3} /$ hour.
From the lake, the water flows into the river Vyatka through the artificially created Ivanovsky canal. During the spring flood, the lake can be directly connected to the river. Every month, the accredited laboratory of the TPP conducts quantitative chemical analyses of the wastewater entering Lake Ivanovskoye, and waters in the canal, which connects the reservoir with the Vyatka river. The work analyzes the data for 2007-2017.

The water from the surface layer of the lake in the summer of 2017 was also taken. Wastewater and natural water were analyzed according to the following indicators: $\mathrm{pH}$, hardness, total biological oxygen demand (BOD-20), mass concentration of dry residue, content of chloride ions, ammonium ions, sulfate - ions, calcium, dissolved oxygen, aluminum, fluoride ions, iron.

In order to achieve the goal of work in 2017 , the water samples were subjected to bioassay. The certified methods for recording the mortality of Daphnia magna Straus (1820) [Federal Register FR 1.39.2007.03222. 2007], for the growth of biomass Scenedesmus quadricauda (Turp.) Breb. by using the method of direct counting in the Goryaev chamber [Federal Register FR 1.39.2007.03223. $2007]$, by the change in the chemotaxis of Paramecium caudatum Ehrenberg (1838) [Federal Register FR 1.39.2015.19242. 2015] and by the bioluminescence of the bacterial preparation «Ecolum» based on the conditionally non-pathogenic strain of Escherichia coli Migula (1895) [Environmental Regulatory Document PND F T 14.1:2:3:4.11-04. T.16.1:2:3:3.8-04. 2010].

The bioindication of the anthropogenic impact on the reservoir was also carried out in 2017 for the indicator species of coastal aquatic vegetation. The authors used a method developed by the scientific school of Moscow State University, equipped with classification scales for determining the trophicity and degree of pollution of the water body by indicator plants, macrophytes and their frequency of occurrence [Melekhova and

Table 1. Morphometric and hydrological characteristics of Lake Ivanovskoe

\begin{tabular}{|l|c|}
\hline \multicolumn{1}{|c|}{ Indicators } & Value \\
\hline The volume of the lake & 21.8 thousand $\mathrm{m}^{3}$ \\
\hline Water surface area & $5.74 \mathrm{ha}$ \\
\hline The length of the lake & $3.8 \mathrm{~km}$ \\
\hline The average depth of the lake & $4 \mathrm{~m}$ \\
\hline Water level fluctuations & less than $1 \mathrm{~m}$ \\
\hline Water exchange intensity factor & $\begin{array}{c}\text { more than } 50 \\
\text { intensive }\end{array}$ \\
\hline
\end{tabular}


Sarapul'tseva 2010]. The principle of the method is based on the varying degrees of adaptation of indicator plants to the complex level of pollution of the reservoir.

In the case of the presence of several indicator plants in the reservoir, the sum of all frequencies of occurrence was calculated, the product of the degree of pollution was found, and then these products were summed up for all species found in this reservoir. The resulting sum of products was divided by the sum of frequencies: the coefficient indicates the overall degree of pollution [Melekhova and Sarapul'tseva 2010].

\section{RESULTS AND DISCUSSION}

\section{Chemical analysis}

The results of the chemical analysis of waste and natural waters over a ten-year period showed that the main pollutant is the ammonium ion. Exceeding of its standards in the samples is noted annually. The maximum concentrations of ammonium ions were found in the channel from Lake Ivanovskoye in the river Vyatka: from 0.79 to $3.17 \mathrm{mg} / \mathrm{dm}^{3}$, which is $1.6-6.3$ times higher than the Russian fish industry standard. At the same time, in the analyzed wastewater, the standard for the ammonium ion was not exceeded, although it often reached the level of 0.5 MPC. This result indicates the likely presence of unaccounted wastewater discharges from the nearby enterprises and / or the input of the ammonium form of nitrogen as a result of decomposition of dead organic residues. In any case, an increase in the level of ammonium ions indicates recent pollution, most often associated with wastewater discharge [Karri, Sahu and Chimmiri 2018].

Through the water outlet No.2, blow-down waters of the ash removal system are discharged, which naturally lead to an increase in the $\mathrm{pH}$ value to 8.41-9.01 units at a rate of 6.5-8.5. Moreover, insignificant excess of the standard in terms of total biological oxygen consumption was regularly noted: up to $1.4 \mathrm{MPC}$ in the wastewater of both outlets. Isolated cases of exceeding the content of oil and oil products were found, for example, in outlet No. 2 by 1.24 times.

In general, the wastewater from outlet No. 2 is more polluted than the water from the outlet No. 1. For the wastewater at TPP, only mechanical treatment is provided, which does not allow bringing the discharged water to the standard quality.
The water samples from Lake Ivanovskoye were taken from the middle part once in 2019 to compare the results with the data of bioindication and bioassay. The content of ammonium ions was found to be $1.8 \pm 0.3 \mathrm{mg} / 1$ and biological oxygen consumption (for 20 days) at the level of $9.1 \pm 0.4 \mathrm{mg} \mathrm{O}_{2} / 1$, which exceeds the MPC for fishery reservoirs by 3.5 and 3 times, respectively. Moreover, these outlets of wastewater from the TPP create local thermal pollution on the lake in winter. The temperature of the discharged water varies within $7-15^{\circ} \mathrm{C}$ with the standard for the enterprise being $16-23^{\circ} \mathrm{C}$.

Thus, high content of the ammonium form of nitrogen and an increased BOD-20 index suggest the presence of the pollution with organic substances of anthropogenic origin in Lake Ivanovskoye. Regular intake of this kind of pollution creates the danger of eutrophication of the water body.

\section{Bioassay}

During the bioassay, the principle of "battery of biotests" was implemented. Four different methods for determining the toxicity of samples were used, which is already a generally accepted practice [Pandard et al. 2006; Zovko et al. 2015]. The results are shown in Table 2.

The bioassay results are consistent with the chemical analysis data in the following way: the maximum toxicity levels were found for the samples from the second water outlet. According to the «Ecolum» test system for E. coli, the «T» index refers to the $2^{\text {nd }}$ group of toxicity out of three possible ones (average toxicity). The toxicity index in the bioassay for P. caudatum also approaches group 2. The algae $S$. quadricauda and lower crustaceans $D$. magna did not show any response to pollution.

The rest of the samples, in accordance with the used bioassay methods, should be recognized as safe. The low information content of biotests for the death of organisms is quite understandable and clear from a toxicological point of view. The methodological approach proposed in the work [Ol'kova 2017], where the tests using daphnia are not criticized, but a list of test functions is given, owing to which it is possible to identify low doses of contaminants, can be accepted.

The increase in the biomass of protococcal algae is slightly higher in natural waters in comparison with the indicators obtained for wastewater. This fact was explained by the presence of a set of biogenic elements necessary for autotrophs 
Table 2. Bioassay of wastewater from TPP and natural waters of Lake Ivanovskoe

\begin{tabular}{|l|c|c|c|c|}
\hline \multirow{2}{*}{ Place of sampling of water } & \multicolumn{3}{|c|}{ Result of bioassay according to the reaction of different test organisms } \\
\cline { 2 - 5 } & $\begin{array}{c}\text { Mortality of } \\
\text { D. magna, } \%\end{array}$ & $\begin{array}{c}\text { Increase in biomass } \\
\text { S. quadricauda, \% to } \\
\text { control }\end{array}$ & $\begin{array}{c}\text { Toxicity index «T» } \\
\text { P. caudatum, s.u. }\end{array}$ & $\begin{array}{c}\text { Toxicity index «T» } \\
\text { E. coli, s.u. }\end{array}$ \\
\hline WW, water outlet No.1 & 0 & $7 \pm 0.7$ & $0.15 \pm 0.08$ & $12.5 \pm 1.6$ \\
\hline WW, water outlet No.2 & 0 & $8 \pm 1.1$ & $0.36 \pm 0.06$ & $26.6 \pm 5.1$ \\
\hline $\begin{array}{l}\text { SW, } 500 \text { m away from the } \\
\text { water outlet }\end{array}$ & 0 & $21 \pm 1.9$ & $-0.18 \pm 0.06$ & $-40.5 \pm 11.6$ \\
\hline $\begin{array}{l}\text { SW, 3000 away from the } \\
\text { water outlet }\end{array}$ & 0 & $15 \pm 0.9$ & $-0.22 \pm 0.9$ & $-36.7 \pm 9.5$ \\
\hline Canal of Lake Ivanovskoe & 0 & $14 \pm 0.9$ & $-0.25 \pm 0.07$ & $-15.4 \pm 5.4$ \\
\hline
\end{tabular}

Note: WW - wastewater, SW - surface water

for their growth and reproduction in natural waters. Probably, the same reason led to negative toxicity indices (stimulation of the test reaction) in the experiments with P. caudatum and a bacterial preparation based on E. coli. It is known that the phenomenon of hormesis, stimulation of vital functions, can be considered as a toxic effect [Erofeeva 2014]. In our case, the stimulation of the test organisms is probably associated with the entry of organic matter into the lake. This is indirectly evidenced by the quarterly BOD-20 values according to the laboratory at the TPP, which are close to the established standard, and the excess of the standard for this indicator by 3 times that was found (mentioned above).

Thus, when comparing the results of chemical analysis and bioassay, no strict correlation has been established, but a number of logical patterns can be traced: the level of pollution is not lethal for organisms, but the effects of stimulating various reactions are observed. This is indicative of the initial manifestations of toxic stress.

\section{Bioindication}

A preliminary geobotanical description was carried out at the survey sites of Lake Ivanovskoye. On the shores of the lake, a uniform border type of overgrowth was noticed. Emerging vegetation makes up $70 \%$ and underwater $-30 \%$ of the total composition. There are no plants in the community that could form an obvious layering. During the study, 20 plant species from 12 families were collected at the registration sites. The prevailing species are Species of the Cereals family; 2 species from the water plantain (Alismataceae) and pondwees (Potamogetonaceae) families were found.

Accounting for the indicator species of coastal aquatic vegetation of Lake Ivanovskoe, which receives wastewater from the TPP, was carried out at two sites $(10 * 10 \mathrm{~m})$. The first was located at a distance of $500 \mathrm{~m}$ from the outlet of the ash removal system blow-off water, the second - at a distance of $1000 \mathrm{~m}$ from the discharge of this wastewater. A certain point was assigned to the identified indicator species, according to which, depending on their frequency of occurrence, the trophicity of the reservoir was calculated (Table 3 ).

The results of bioindication at the counting sites indicate an increase in the trophicity of Lake Ivanovskoe approaching the place of wastewater discharge. The species composition of coastal aquatic vegetation is enriched with indicator species, which, on the one hand, are resistant to pollution by some chemical elements, and on the other hand, are adapted to use the increased content of nutrients to realize their biological potential. The disappearance of indicator mesotrophs at the maximum distance from the WW discharge site $(3000 \mathrm{~m})$ indicates the anthropogenic nature of the trophicity increase in the reservoir due to pollution with organic matter and biogenic elements.

Further, on the selected counting sites, an indication of the water quality in Lake Ivanovskoye by the presence of indicator species with different resistance to the prevailing level of pollution was carried out. Each detected macrophyte plant species corresponds to a score for determining the level of pollution, which is adjusted depending on the frequency of their occurrence. As a result, the level of pollution was calculated (Table 4).

Moving from the background site to the place of wastewater discharge it was noticed that the number of pollution indicator species, as well as the frequency of their occurrence, gradually increase. Although not extreme, it was reflected in the results of the survey of the accounting sites. The data confirm that the wastewater pollution from thermal power plants affects the ecosystem of the lake. However, there is also a positive fact: 
Table 3. Determination of the trophicity of a reservoir by indicator species of coastal aquatic vegetation

\begin{tabular}{|c|c|c|c|}
\hline Indicator species & $\begin{array}{l}\text { Score for determining } \\
\text { trophicity (1) }\end{array}$ & $\begin{array}{l}\text { Frequency of occurrence } \\
\qquad(2)\end{array}$ & $\begin{array}{c}\text { Trophicity of a reservoir by } \\
\text { species } \\
(1) \times(2)=(3)\end{array}$ \\
\hline \multicolumn{4}{|c|}{ Evaluation site No. 1: $500 \mathrm{~m}$ downstream from the point of discharge of blowdown water from the ash removal system } \\
\hline Comarum palustre & 1 & 3 & 3 \\
\hline Carex vesicaria & 3 & 7 & 21 \\
\hline Nuphar lutea & 1 & 1 & 1 \\
\hline Alisma plantago-aquatica & 3 & 7 & 21 \\
\hline Amount & - & 18 & 46 \\
\hline The trophicity index of the reservoir & & $\begin{array}{c}46: 18=2.6 \\
\text { Mesotrophic type }\end{array}$ & \\
\hline \multicolumn{4}{|c|}{ Evaluation site No. 2: $1000 \mathrm{~m}$ downstream of the discharge point blowdown water of the ash removal system } \\
\hline Nuphar lutea & 1 & 1 & 1 \\
\hline Alisma plantagoaquatica & 3 & 5 & 15 \\
\hline Amount & - & 6 & 16 \\
\hline The trophicity index of the reservoir & \multicolumn{3}{|c|}{$\begin{array}{c}16: 6=2.6 \\
\text { Mesotrophic type }\end{array}$} \\
\hline \multicolumn{4}{|c|}{$\begin{array}{c}\text { Background registration site: the opposite bank from the wastewater inlet, } \\
\text { at the maximum distance from the discharge }\end{array}$} \\
\hline Not met & & & \\
\hline
\end{tabular}

Note: To determine the frequency of occurrence of detected macrophytes a scale with the following designations was used: 1 - very rarely, 2 - rarely, 3 - not rarely, 5 - often, 7 - very often, 9 - mass.

Table 4. Determination of the level of pollution of Lake Ivanovskoye by indicator species of macrophytes

\begin{tabular}{|c|c|c|c|}
\hline Indicator species of macrophyte plants & Score for defining pollution & $\begin{array}{c}\text { Frequency of occurrence } \\
\text { of indicator species }\end{array}$ & Pollution index and level \\
\hline \multicolumn{4}{|c|}{ Evaluation site No. 1: $500 \mathrm{~m}$ downstream from the point of discharge of blowdown water from the ash removal system } \\
\hline Potamogeton perfoliatus & 3 & 3 & \multirow{2}{*}{$\begin{array}{c}3.5 \\
\text { borderline pollution level } \\
\text { strong / moderate }\end{array}$} \\
\hline Ceratophyllum demersum & 5 & 1 & \\
\hline \multicolumn{4}{|c|}{ Evaluation site No. 2: $1000 \mathrm{~m}$ downstream from the point of discharge of blowdown water from the ash removal system } \\
\hline Potamogeton perfoliatus & 3 & 5 & $\begin{array}{c}15 \\
\text { moderate pollution }\end{array}$ \\
\hline \multicolumn{4}{|c|}{ Background registration site: the opposite bank from the wastewater inlet, at the maximum distance from the discharge } \\
\hline Not met & - & - & low level of pollution \\
\hline
\end{tabular}

the process did not affect the entire reservoir. Due to the biota, a partial self-purification of the reservoir occurs with a gradual increase in the level of its trophicity.

Thus, according to the main chemical effect on the water body, it was possible to predict its eutrophication. The bioindication results have confirmed this hypothesis. Moderate pollution of the lake was diagnosed, the ecological type of the reservoir is mesotrophic. The literature contains the information on the high information content of the characteristics of coastal plant communities, which correlate with such indicators of the aquatic environment as dissolved oxygen, water temperature, turbidity, total suspended sediment content, nitrates and orthophosphates [Aguiar et al. 2009; Alemu et al. 2018].

\section{CONCLUSIONS}

Many reservoirs, which could be valuable as fishery and recreational facilities, become wastewater receivers. A comprehensive diagnosis of the ecological state of Lake Ivanovskoye, carried out using the triadic approach, has been shown. The lake is connected with the river. Vyatka is the main waterway of the Kirov region and a source of drinking water supply for many settlements. On the basis of the results obtained from the chemical analysis of wastewater from a thermal power plant entering the lake, priority pollutants were identified: ammoniacal nitrogen and organic matter (according to BOD-20). This type of pollution usually leads to the eutrophication processes to varying degrees. It was confirmed by accounting 
for the indicator macrophytes, some of which simultaneously indicated a moderate level of pollution of the reservoir. The «battery of biotests» we have chosen has consistently confirmed the increased hazard of wastewater compared to the surface waters of Lake Ivanovskoe. However, a moderate level of lake pollution detected during bioindication has not been established. In conclusion, it should be mentioned that a comprehensive study of a reservoir always has a greater diagnostic value than any group of methods taken separately.

\section{REFERENCES}

1. Aguiar, F.C., Ferreira, M.T., Albuquerque, A., Rodriguez-Gonzalez, P., Segurado, P. 2009. Structural and functional responses of riparian vegetation to human disturbance: Performance and spatial scaledependence. Fundamental and Applied Limnology, 175(3), 249-267.

2. Alemu, T., Bahrndorff, S., Pertoldi, C., Hundera, K., Alemayehu, E., Ambelu, A. 2018. Development of a plant based riparian index of biotic integrity (RIBI) for assessing the ecological condition of highland streams in East Africa. Ecological Indicators, 87, 77-85. DOI: 10.1016/j.ecolind.2017.12.032.

3. Chapman, P. M. 1986. Sediment quality criteria from the sediment quality triad - an example. Environmental Toxicology and Chemistry, 5(11), 957-964.

4. Directive 2000/60/EC of the European Parliament and of the Council establishing a framework for the Community action in the field of water policy - EU Water Framework Directive (as amended on October 20, 2014). 2000. Available at: https://eur-lex.europa.eu/ legal-content/EN/TXT/?uri=CELEX:32000L0060 [Accessed 14.09.2020].

5. Environmental Regulatory Document PND FT 14.1:2:3:4.11-04. T.16.1:2:3:3.8-04. 2010. Method for determining the integrated toxicity of surface waters, including marine, ground, drinking, waste waters, water extracts from soils, waste, sewage sludge by changes in bacterial bioluminescence using the Ecolum test-system. Moscow: Nera-S, 30 p.

6. Erofeeva, E.A. 2014. Hormesis and paradoxical effects upon exposure to pollutants. Dose-Response, 12(1), 121-135.

7. Federal Register FR 1.39.2007.03222. 2007. Methodology for determining the toxicity of water and water extracts from soils, sewage sludge, and waste by mortality and changes in fertility of daphnias. Moscow: Akvaros. 51 p.

8. Federal Register FR 1.39.2007.03223. 2007. Methodology for determining the toxicity of water, water extracts from the soil, sewage sludge and waste by changing the level of chlorophyll fluorescence and the number of algae cells. Moscow: Akvaros. $50 \mathrm{p}$.

9. Federal Register FR 1.39.2015.19242. 2015. Environmental Regulatory Document PND F T 16.2:2.298. Methodology for determining the toxicity of samples of natural, drinking, domestic and drinking, household waste, treated sewage, waste, thawed, technological water by the express method using the Biotester device. St. Petersburg: Spektrum, p. 21.

10. Hong, Y.K., Yoon, D.H., Kim, J.W., Chae, M.J., Ko, B.K., Kim, S.C. 2020. Ecological risk assessment of heavy metal-contaminated soil using the triad approach. Journal of Soils and Sediments. DOI: 10.1007/s11368-020-02750-9.

11. Karri, R.R., Sahu, J.N., Chimmiri, V. 2018. Critical review of abatement of ammonia from wastewater. Journal of Molecular Liquids, 261, 21-31, DOI: 10.1016/j.molliq.2018.03.120.

12. Klimkowicz-Pawlas, A., Maliszewska-Kordybach, B., Smreczak, B. 2019. Triad-based screening risk assessment of the agricultural area exposed to the long-term PAHs contamination. Environmental Geochemistry and Health, 41(3), 1369-1385, DOI: 10.1007/s10653-018-0220-y.

13. Melekhova, O.P., Sarapul'tseva, E.I. 2010. Biological control of the environment: bioindication and bioassay. Moscow: Akademiya. 288 p.

14. Ol'kova, A.S. 2017. The conditions of cultivation and the variety of test functions of Daphnia magna Straus in bioassay. Water and ecology: problems and solutions, 1, 64-82. DOI: 10.23968/2305-3488.2017.22.4.111-115.

15. Pandard, P., Devillers, J., Charissou, A.M., Poulsen, V. 2006. Selecting a battery of bioassays for ecotoxicological characterization of wastes. Science of the Total Environment, 363, 114-125.

16. Slimani, N., Jimenez, J.J., Guilbert, E., Boumaiz, M., Thioulouse, J. 2020. Surface water quality assessment in a semiarid Mediterranean region (Medjerda, Northern Tunisia) using partial triadic analysis. Environmental Science and Pollution Research, 27(24), 30190-30198 DOI: 10.1007/ s11356-020-09326-7.

17. Stesevic, D., Feiler, U., Sundic, D., Mijovic, S., Erdinger, L., Seiler, T.B., Heininger, P., Hollert, H. 2007. Application of a new sediment contact test with Myriophyllum aquaticum and of the aquatic Lemna test to assess the sediment quality of Lake Skadar. Journal of Soils and Sediments, 7(5), 342349, DOI: $10.1065 /$ jss2007.08.249.

18. Water Code of the Russian Federation (as amended on December 27, 2018). 2006. Available at: http:// docs.cntd.ru/document/901982862 [Date accessed 02.05.2019].

19. Zovko, M., Vidaković-Cifrek, Ž., Cvetković, Ž., Bošnir, J. 2015. Assessment of acrylamide toxicity using a battery of standardised bioassays. Archives of Industrial Hygiene and Toxicology, 66, 315-321. 